\title{
ANALITICAL STUDY OF STREAM FREQUENCY AND DRAINAGE DENSITY OF UPPER NARMADA BASIN: A REMOTE SENSING AND GIS APPROACH
}

\author{
Vinay Raikwar ${ }^{1}$ and Pramod Pagare ${ }^{2}$ \\ Research Scholar ${ }^{1}$, Professor ${ }^{2}$ \\ Department of Geography, Govt. M.G.M. P.G. College, Itarsi, Hoshangabad (MP) India \\ Email: vinay.utd@gmail.com
}

\begin{abstract}
The present paper deals with analysis of stream frequency and drainage density of upper Narmada Basin in Central India. Hortan's method is used to get desired result. Stream frequency and Drainage density are two important factors that control the speed of run off in heavy rain. The faster runoff determines the grater density and frequency of streams. It is observed that Upper Narmada basin has lowest drainage density indicating higher rate of infiltration greater subsurface flow, high moisture retentive capacity and relatively low relief, and highest drainage density indicating lower rate of infiltration and more runoff than other area, because basin having part of rocky barren land which has less permeability that's why in this area groundwater table is not well developed. The highest drainage frequencies are reported from the central, northern and eastern part of the basin, which area indicating high permeable geology and low relief. While the lowest drainage frequencies are observed over the peripheral part of the basin, which is having impermeable subsurface and sparse vegetation and high relief conditions.
\end{abstract}

Key words: Drainage Density, Stream frequency, Spatial Analysis, Upper Narmada Basin

\section{Introduction}

A drainage basin is defined as an area drained by river and its tributaries. A basin is a natural hydrological feature in which various channel, drains and streams are seen is as surface runoff. The analysis of stream frequency and drainage density is used to manage various aspects such as drinking water supply, observing runoff, erosion, irrigation, pollution etc. Remote sensing and GIS techniques are important tools in the determination of morphometric analysis of the drainage basin. It plays significant role in providing spatial data required for calculations of morphometric indices like steam frequency and drainage density etc. The total length of streams of all orders per drainage area is called Drainage density. Drainage density factor has been related to climate, rocks types, relief, infiltration capacity, the cover of vegetation and surface roughness (Horton, 1932). According to Horton (1932), Drainage Density is defined ratio of the total length of all stream segments in a given drainage basin to the total area of that basin. According to Horton (1932), stream frequency is the total number of stream segments of all orders per unit area. Stream frequency is the measure of the number of streams per unit area (Horton, 1945). A higher stream frequency indicates the higher surface runoff and steep ground surface. Stream frequency or drainage frequency is the measure of the number of streams per kilometer area. According to Rogers (1971), high drainage density is represented by metamorphic rocks, whereas a sedimentary rock shows low drainage values.

\section{Study Area}

The area under "Upper Narmada Basin " comprises of a fairly large tract lying between $21^{\circ} 41^{\prime}$ North to $23^{\circ} 46^{\prime}$ North latitude and from $79^{\circ} 17^{\prime}$ East to $81^{\circ} 46^{\prime}$ East longitude. The area comes under the tropical belt and location of the area is itself significant. The Narmada River rises in the Amarkantak plateau of Maikal Range in the 'Anuppur' District of Madhya Pradesh at an elevation of 1057 meters above sea level. The river travels a distance of $1312 \mathrm{kms}$, before it falls in to Gulf of Cambay in the Arabian Sea near Bharuch in Gujarat. The Narmada Basin hemmed between Vindhyachal and Satpura ranges extend over and area of $98,796 \mathrm{kms}^{2}$. The basin covers and large area of Madhya Pradesh (86 percent), Gujarat (14 percent) and comparatively smaller area (2 percent) in Maharashtra. About 35 percent of the basin area in under forest cover, 60 percent under arable land and 5 percent is grassland, wasteland etc. 
The climate is humid tropical. Average Rainfall of Basin is $1178 \mathrm{~mm}$. whereas average temperature ranges is $25.80 \mathrm{C}$.

\section{Figure 01: Location Map of upper Narmada Basin}

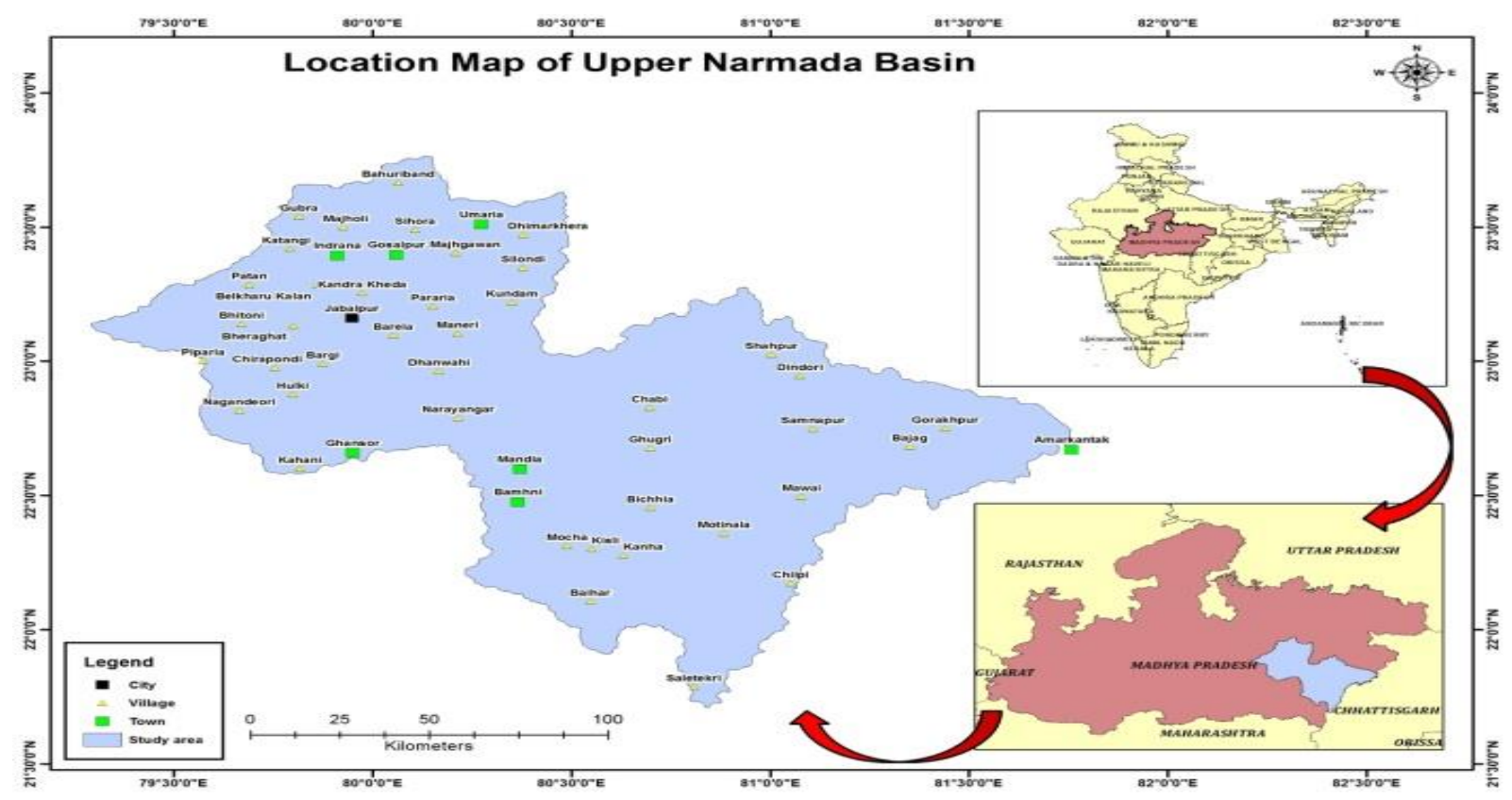

\section{Objectives}

- Mapping and Analysis of drainage density.

- Mapping and Analysis of Stream frequency.

- Study of correction between stream frequency and drainage density.

\section{Data Source and Methodology}

To get drainage density and stream frequency, drainage map is prepared by scanning of survey of India topographic sheets on 1:50,000 scale by Global Mapper 10.2 GIS software. After geo referencing top sheets are compiled in single mosaic. Stream order is calculated using Strahler (1953) system in Arc GIS 10.6 software. While the stream length, total basin area, perimeter were measured with the help of Arc GIS 10.6 software. The entire catchment and mainstream has been prepared from the DEM prepared by Top sheet contour and ILWIS 3.7.Hortan Method (1932) Used to get desired results. Hortan suggested stream frequency is the dividend of numbers of streams $(\mathrm{NU})$ with the area of drainage basin $(\mathrm{A})$.

Stream frequency $\left(D_{F}\right)=N U / A$

Whereas drainage density is the total number of stream Lengths in the basin (LU) divided by the area of basin $(A)$.

Drainage density $\left(D_{D}\right)=L U / A$.

\section{RESULT AND DISCUSSION \\ Drainage Density $\left(D_{D}\right)$}

The special analysis showed the drainage density is range from 0 to $6 \mathrm{~km}$ per sq $\mathrm{km}$ (Table 4.1) and the very low drainage density ( 0 to 1$)$ value is attributed due to the presence of permeable subsurface formation, dense vegetation and low relief (Langbein, 1947; Nag, 1998). Drainage density characterizes the textural measure independent of basin size and considered to be a function of climate, lithology, stage of development, etc. it is a measure of drainage dissection that reflects the competing effectiveness of overland flow and infiltration. Horton (1945) reasoned that basins of low drainage density are the product of runoff processes dominated by infiltration and subsurface flow, whereas basins of high drainage density are the product of erosion and dissection by overland flow. Higher drainage density also indicates the decrease in the length of overland flow with increase in angle of hill slope (Schumm, 1956). It is observed that Upper Narmada basin has lowest drainage density ( 0 to $1 \mathrm{~km} / \mathrm{sq} \mathrm{km}$ ) covers 164.59 sq. $\mathrm{km}$ (0.71 percent) area of the basin, indicating higher rate of infiltration greater subsurface flow, high moisture retentive capacity and relatively low relief, and highest drainage density (4-6 km/sq km) covers $4436.37 \mathrm{sq}$. km (19.21 percent) area of the basin, indicating lower rate of infiltration and more runoff than other area, because basin having part of rocky 
barren land which has less permeability that's why in this area groundwater table is not well developed. Table 01 shows the spatial analysis of drainage density of the Upper Narmada basin. All these facts of the spatial analysis of Drainage density clearly indicate the asymmetrical distribution of Drainage density of the basin.

Table 01: Spatial Analysis of Drainage Density

\begin{tabular}{|l|c|c|}
\hline Drainage Density(km./km $\left.{ }^{2}\right)$ & Area (sq.km.) & Area (\%) \\
\hline $0--1$ & 164.59 & 0.71 \\
\hline $1--2$ & 1085.92 & 4.70 \\
\hline $2--3$ & 2298.59 & 9.96 \\
\hline $3--4$ & 15103.53 & 65.41 \\
\hline $4--6$ & 4436.37 & 19.21 \\
\hline & 23089.00 & 100.00 \\
\hline
\end{tabular}

Figure 02: Upper Narmada Basin Drainage Density

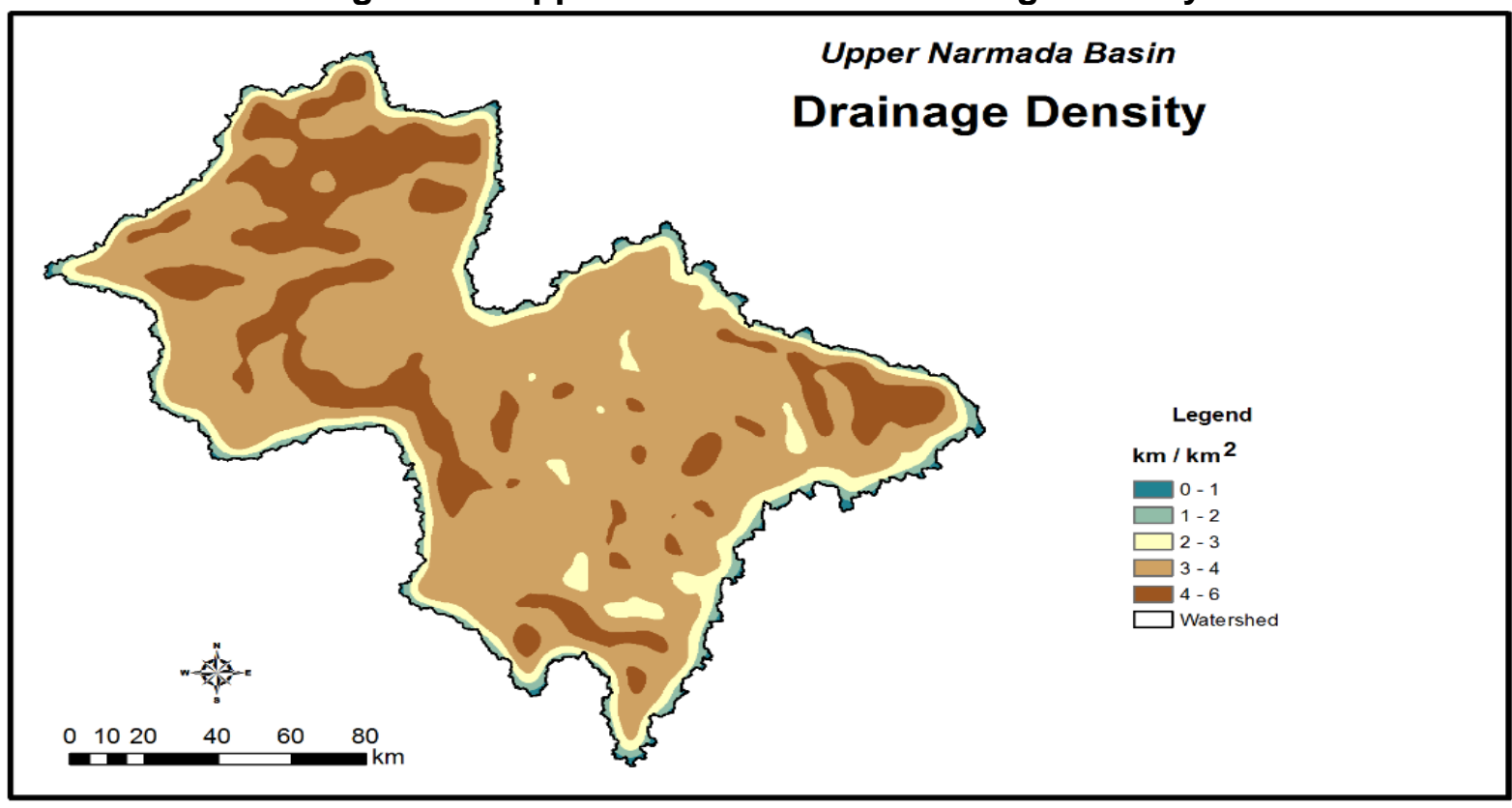

\section{Stream Frequency}

For the computation of stream frequency, the Upper Narmada basin is conveniently divided into the grid of one square kilometer; then the number of streams are counted in each grid of one square kilometer and tabulated for quantification. The data of stream frequencies are classified as a fixed Class interval as 4 streams per square kilometer area. The highest drainage frequencies (16 to 20 Streams per sq. km) are reported from the central, northern and eastern part of the basin, which area indicating high permeable geology and low relief. While the lowest drainage frequencies ( 0 to 4 Streams per sq. $\mathrm{km}$ ) are observed over the peripheral part of the basin, which is having impermeable subsurface and sparse vegetation and high relief conditions. Table 02 shows the spatial analysis of stream frequency of the Upper Narmada basin. All these facts of the spatial analysis of stream frequency clearly indicate the asymmetrical distribution of stream frequency of the basin.

Table 02: Spatial analysis of Stream Frequency

\begin{tabular}{|l|c|c|}
\hline Stream Frequency $\left(\right.$ Streams $\mathbf{~ k m ~}^{\mathbf{2}}$ ) & Area (sq.km.) & Area (\%) \\
\hline $0--4$ & 182.56 & 0.79 \\
\hline $4--8$ & 951.60 & 4.12 \\
\hline $8--12$ & 7980.74 & 34.57 \\
\hline $12--16$ & 12303.13 & 53.29 \\
\hline $16--20$ & 1670.97 & 7.24 \\
\hline & 23089.00 & 100.00 \\
\hline
\end{tabular}




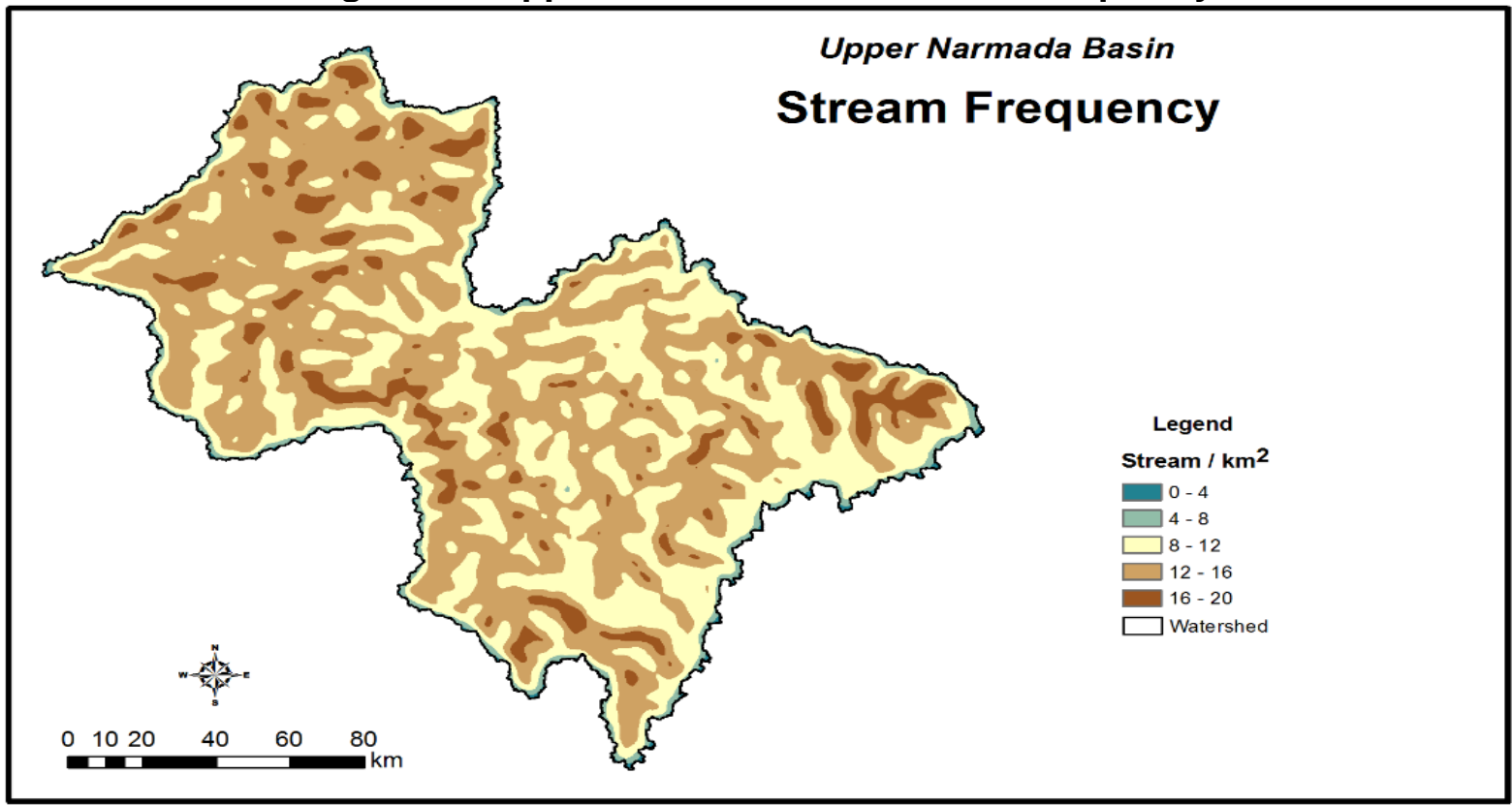

\section{Conclusion}

It is observed that Upper Narmada basin has lowest drainage density ( 0 to $1 \mathrm{~km} / \mathrm{sq} \mathrm{km}$ ) covers $164.59 \mathrm{sq} . \mathrm{km}$ ( 0.71 percent) area of the basin, indicating higher rate of infiltration greater subsurface flow, high moisture retentive capacity and relatively low relief, and highest drainage density (4-6 km/sq km) covers $4436.37 \mathrm{sq}$. km (19.21 percent) area of the basin, indicating lower rate of infiltration and more runoff than other area, because basin having part of rocky barren land which has less permeability that's why in this area groundwater table is not well developed. The highest drainage frequencies (16 to 20 Streams per sq. km) are reported from the central, northern and eastern part of the basin, which area indicating high permeable geology and low relief. While the lowest drainage frequencies (0 to 4 Streams per sq. $\mathrm{km}$ ) are observed over the peripheral part of the basin, which is having impermeable subsurface and sparse vegetation and high relief conditions. High Correlation is found between stream frequency and drainage density. The High range of drainage frequency and density indicates the mature stage of basin.

\section{Reference}

1. Singh, Savindra (1999) Geomorphology, Prayag Pustak Bhavan, Allahabad.

2. Strahler, A.N., (1946) Quantitative geomorphology of drainage basin and channel networks, in: V.T. Chow (ed). Handbook of Applied Hydrology, McGraw Hill Book Company, New York, Section, 4-11.

3. Kumar Vipin (2017) Study of Drainage Frequency and Drainage Density of somb drainage Basin in lower Shiwalik Hills, India, International Journal of Arts, Humanities and Management Studies Vol. 03 pp-83-92

4. Nag, S.K. (1998) "Morphometric analysis using remote sensing techniques in the Chaka sub-basin, Purulia District, West Bengal, Journal of the Indian Society of Remote Sensing, Vol. 26, No. 1 \& 2, pp 69-76.

5. Rogers, W.J. (1971) Hydrograph analysis and Some Related Variables in Quantitative Geomorphology- Some Aspect and Applications M. Morisowa, Ed. Binghamto, New Yark, State University of New Yark.

6. Horton, R.E, (1945) Erosional development of stream and their drainage basin: Hydrological approach to quantitative morphology, Bull Geol. Soc, Amer., V. 56, pp 275.

7. Langbein,W.B., (1947) Topographic characteristics of drainage basin: U.S. Geol. Survey Water-supply Paper 968- C, p. 125-157.

8. Schumn, S.A. (1956) Evolution of Drainage System and Slope in Badlands at Parth Amboy, New Jersey. Bulletin Geological Society of America, Vol. 67, pp 597-646. 